\title{
Youth Development Programs in Lithuania: Prevention and Positive Youth Development
}

\author{
Ingrida Gabrialavičiūtè ${ }^{1}$, Saulè Raižienė ${ }^{1}$, Inga Truskauskaitè-Kunevičienè ${ }^{1} \&$ Renata Garckija $^{1}$ \\ ${ }^{1}$ Mykolas Romeris University, Vilnius, Lithuania \\ Correspondence: Ingrida Gabrialavičiūtè, Mykolas Romeris University, Ateities str.20, Vilnius, 08303, Lithuania. \\ Tel: 370-5-271-4620. E-mail: ingrida_gab@mruni.eu
}

Received: April 24, 2014

doi:10.5539/ijps.v6n3p13

\author{
Accepted: May 16, $2014 \quad$ Online Published: June 26, 2014 \\ URL: http://dx.doi.org/10.5539/ijps.v6n3p13
}

\begin{abstract}
The current review aims at evaluating the correspondence of prevention programs for late adolescents (15-19 years) implemented in Lithuania in 2006-2013 with PYD framework. Fifteen programs were included in the final analysis for this review. We used the criteria of positive youth development programs identified by Roth \& Brooks-Gunn (2003a): program goals, activities and atmosphere. We also included measurement of program outcomes and structure of the curriculum as additional criteria. Youth development programs implemented in Lithuania contain several features consistent with PYD conception. The range of goals offered by the programs match all the $5 \mathrm{Cs}$ of thriving, however Lithuanian prevention programs are not aimed at promotion of Caring and Connections as much as Competence, Character and Confidence. The duration of the programs does not create the sufficient prerequisites for supportive atmosphere. Program activities are mostly oriented at providing knowledge. The effect of the programs is uncertain, because of the absence of the most important features of effective youth development programs identified in other cultural contexts. In addition, we summarized the implications of this review for future developers of youth development programs in Lithuania: PYD conception should be utilized as the theoretical basis as well as assurance of implementation quality and use of quasi-experimental design of effectiveness measurement.
\end{abstract}

Keywords: positive youth development, prevention, youth development programs, late adolescents

\section{Introduction}

In the late 1990s and early 2000s a field of development science shifted to a new conception of youth as resources to be developed rather than problems to be managed (Silbereisen \& Lerner, 2007). This new positive youth development (PYD) perspective moved beyond the negative, deficit view of youth towards a view of the strengths of youth and the positive qualities and outcomes we wish our youth to develop. The theoretical basis of a PYD perspective is the developmental systems theories and the concept of the plasticity of human development about what youth need for successful adulthood (Lerner et al., 2009). Developmental systems model emphasizes that the basic process of adolescent development involves mutually influential relations between the developing individual and the multiple levels of his/her changing context: family, community, schools and the broader society/culture. Relations between individuals and their real-world ecological settings are the bases of variation in the course of human development. When individual-context relations benefit both the person and his ecology, these development regulations may be termed "adaptive" (Lerner et al., 2010).

The process of changes adolescents undergo for growing into a well-adapted adult status may be labeled as thriving. "Five Cs" of positive youth development (competence, confidence, character, connection and caring) were suggested as attributes of a thriving youth (Lerner et al., 2003; King et al., 2005). Researchers argue that young people whose life contained lower amount of five Cs would be at a higher risk for the developmental path that includes personal, social and behavioral problems and risks. Those young people whose lives incorporated these five Cs would be on a development path that results in the development of the sixth $\mathrm{C}$-youth contributions to self, family, community and civil society (Lerner, 2004).

PYD view of adolescent development seeks to identify conditions within the individual and his or her development contexts (families, schools and communities) that make positive developmental processes such as thriving more likely. These resources are so called internal and external developmental assets, and can be seen as building blocks of positive development (Benson, 2003; Yibing et al., 2010). 
Higher number of developmental assets present in adolescents' life contribute to higher levels of thriving, thus, promotion of developmental assets via the mobilization of energies in the individual and institutions seems to be a useful approach for making positive outcomes in children and adolescents more likely (Theokas et al., 2005). Internal assets refer to competences and individual qualities that guide positive choices and help to develop a sense of confidence and purpose. External assets can be summarized in four categories: support, empowerment, boundaries and expectations, and constructive use of time. Resources in families, schools, communities, and the nation can be seen as external assets and provide the experiences and supports youth need to develop characteristics of thriving. When circumstances prevent some families, schools, and communities from providing the fundamental resources, youth development programs can offer additional opportunities for fulfilling those needs. PYD approach to youth programing stimulated critical reappraisal of existing prevention strategy that failed to show the desired effect (Catalano et al., 2004). PYD philosophy emphasized the shift from reduction of single problem behavior to the inclusion of system change. The programs that embraced this new approach proved to be effective (Catalano et al., 2004; Roth \& Brooks-Gunn, 2003). Youth development (YD) programs can provide developmentally rich contexts where relationships form, opportunities for growth in multiple areas proliferate, and development occurs (Roth \& Brooks-Gunn, 2003). Scales et al. (2000) has identified that participation in youth programs has the key asset linked to exemplary positive development. To make meaningful evaluations of the utility of PYD approach for designing successful intervention programs, Roth and Brooks-Gunn (2003a) offered a definition of YD program. They suggested three defining characteristics of YD programs: program goals, program atmosphere, and program activities. They used $5 \mathrm{Cs}$ to identify specific goals for programs promoting positive youth development. Program atmosphere was described by five dimensions: encourage the development of supportive relationships with adults and among peers, empower youth, communicate expectations for positive behavior, provide opportunities for recognition, and provide services that are stable and relatively long-lasting. Program activities that capture youth development philosophy include the opportunity for adolescents to build skills, engage in real and challenging activities, and broaden their horizons.

PYD perspective recognizes contextual variability in youth experiences that shape their development. As noted above, YD programs influence positive outcomes by providing youth with developmental assets. What is considered "healthy" or "optimal" development varies across different settings or cultures making developmentally appropriate tasks culturally unique. Researchers are looking for particular assets that are of specific importance for youth living in specific communities and study positive outcomes taking contextual differences into account (Lerner et al., 2009). In recent years PYD perspective for studying youth development has been adopted by Lithuanian researchers. However, the application of this philosophy didn't extend to the development and evaluation of intervention programs that target well-being of youth. It is likely that various attempts of youth development programs or at least prevention events (e.g. AIDS days, alcohol and tobacco prevention days) were taking place at Lithuanian schools for many years (at least since the Independence when the opportunities to take over the positive practice of other countries became possible). In 2004 the Lithuanian Government issued the resolution on Children and Youth socialization programs. In this document the prevention work at schools was legally defined and this could be considered as an official beginning of implementation of youth development programs in Lithuania.

In 2010 Lithuanian Ministry of Education and Science initiated the review of all the prevention programs implemented in Lithuanian schools during the period 2006-2010. All schools were addressed with the request to list prevention programs they developed and/or implemented. The reviewers concluded that there is a strong need for national registry of prevention programs in education system as well as for recommendations for program development and quality evaluation standards (Auškelis et al., 2010). It could be also noted that the programs used by Lithuanian youth practitioners during the mentioned period were labeled "prevention programs". However, alternative approaches can be used in youth programming. The current review aims at evaluating the correspondence of prevention programs for late adolescents (15-19 years) implemented in Lithuania in 2006-2013 with PYD framework.

\section{Method}

Two sources for program selection were used in this paper: report by Lithuanian Ministry of Education and Science (Auškelis et al., 2010) and grey literature (internet search via searching engine "Google" was conducted, using the search keywords "prevention", "intervention", "life skills", "social skills", "school" in Lithuanian).

The initial number of programs found was 65 . The programs that were accessible for review and targeted youth aged 15 - 19 without any identified adjustment difficulties were selected from this larger base. 25 programs corresponded to these criteria. 10 programs without any available descriptions (either the descriptions were nonexistent or the authors refused to provide them) were excluded. Finally, 15 programs were included in this 
review. 11 programs $(73 \%)$ are originated in Lithuania and other 4 (27\%) in other countries (see Table 2). English titles of the 15 evaluated programs are provided in the tables. For the Lithuanian titles see Appendix 1 (Table A1).

The programs reviewed were carried out mostly in Lithuanian schools but also in various youth centers.

The programs selected for the final review were evaluated according to their correspondence to positive youth development philosophy. We used the criteria of positive youth development programs identified by Roth $\&$ Brooks-Gunn (2003a): program goals, activities and atmosphere.

5Cs were used for identifying the specific goals of programs that promote positive youth development as described by Roth \& Brooks-Gunn (2003a). Competence refers to goals of enhancing participants' social, academic, cognitive, and vocational competencies. Confidence consists of goals aiming at improving self-esteem, self-concept, self-efficacy, identity, and belief in the future. Programs that build and strengthen adolescents' relationship with other people and institutions were considered as promoting connections. Character-building goals can be described as increasing self-control, decreasing engagement in problem behaviors, developing respect for cultural or societal rules and standards and a sense of morality. Caring goals include improving youths' empathy and identification with others. The compliance of program goals to 5Cs was estimated by evaluating the goals and tasks of the programs as well as analyzing the activities and exercises where description of those was provided.

Activities mean the ways by which the program goals are achieved. We investigated the range of program activities in two ways. First, we describe the types of activities offered by programs. We then analyzed these according to domains in which change is made: knowledge, skills and/or attitudes.

Atmosphere is referred to as attitudes of the school staff toward children, their behavior, the very behavior of the staff regarding respect, tolerance (or non-tolerance as in case of bullying). For reflecting program atmosphere we have chosen duration criteria as a proxy indicator as without the sufficient time there is no possibility to create a positive atmosphere (Roth \& Brooks-Gunn, 2003).

We also included other criteria of effective programs described by Catalano et al. (2004) in our study, namely measurement of program outcomes and structure of the curriculum. The information about the age of the target group and the origin of the program was provided as well.

Programs were assessed by four evaluators. The agreement between evaluators was reached when the program goals and activities were ambiguous by the process of discussion. During the discussions the evaluators were going back to the definition of the selection criteria in order to re-evaluate if the programs correspond these criteria.

\section{Results}

\subsection{Program Goals}

The compliance of program goals to $5 \mathrm{Cs}$ is presented in Table 1. Only two (13.3\%) out of fifteen analyzed programs aimed at promoting all five Cs: Big Brothers/Big Sisters program and Olweus Bullying Prevention Program. Operation Snowball program aims at all but Caring dimensions whereas Child and Human rights training program covers all but Connection goals. Thus, two of the analyzed programs (13.3\%) target four PYD goals. Six $(40 \%)$ of the reviewed programs target three PYD goals, however the goals are not the same. There are four (26.7\%) programs that develop Competence, Confidence and Character. Both Human Trafficking prevention program and Suicide prevention program aim at Competence, Caring and Character. From the remaining programs four aimed at only two PYD outcomes and Substance abuse prevention program "Drugs in the Schools: Preventing Substance Abuse" only manages to develop one outcome (Competence). 
Table 1. Proagram goals and activities for the 15 evaluated programs

\begin{tabular}{|c|c|c|c|c|c|c|c|}
\hline & Program & Competence & Confidence & Caring & Connection & Character & Duration \\
\hline 1 & $\begin{array}{l}\text { Olweus Bullying Prevention } \\
\text { Program }\end{array}$ & * & * & * & $*$ & * & 18 months \\
\hline 2 & $\begin{array}{l}\text { Big Brothers Big Sisters } \\
\text { (BB/BS) }\end{array}$ & * & $*$ & $*$ & $*$ & $*$ & 12 months \\
\hline 3 & Operation Snowball & $*$ & * & & * & * & 6-12 months \\
\hline 4 & $\begin{array}{l}\text { Drugs in the Schools: } \\
\text { Preventing Substance Abuse }\end{array}$ & * & & & & & 16 sessions \\
\hline 5 & $\begin{array}{l}\text { Life Skills Development } \\
\text { Programs }\end{array}$ & $*$ & * & & & * & NA \\
\hline 6 & $\begin{array}{l}\text { Alcohol, Tobacco and Other } \\
\text { Substance Abuse Prevention } \\
\text { Program }\end{array}$ & $*$ & & & & * & NA \\
\hline 7 & $\begin{array}{l}\text { Human Trafficking } \\
\text { Prevention program "A } \\
\text { Journey Turned into a } \\
\text { Nightmare" }\end{array}$ & * & & * & & * & 5 sessions \\
\hline 8 & $\begin{array}{l}\text { Child and Human Rights } \\
\text { Training Program }\end{array}$ & $*$ & $*$ & $*$ & & $*$ & 15 sessions \\
\hline 9 & $\begin{array}{l}\text { Career Guidance and } \\
\text { Counseling Program }\end{array}$ & $*$ & * & & & & 16 sessions \\
\hline 10 & Social resistance program & $*$ & & & & $*$ & 13 sessions \\
\hline 11 & Self-Awareness Program & * & * & & & & 10 sessions \\
\hline 12 & $\begin{array}{l}\text { Social Skills Development } \\
\text { Program }\end{array}$ & * & $*$ & & & $*$ & 18 sessions \\
\hline 13 & $\begin{array}{l}\text { Adolescents' Resilience } \\
\text { Training Program }\end{array}$ & $*$ & * & & & * & 13 sessions \\
\hline 14 & $\begin{array}{l}\text { Preparation for Family Life } \\
\text { and Sexuality Education } \\
\text { Program }\end{array}$ & $*$ & $*$ & & & $*$ & NA \\
\hline 15 & $\begin{array}{l}\text { Suicide Prevention Program } \\
\text { "Choose Life" }\end{array}$ & $*$ & & $*$ & & * & 3 sessions \\
\hline
\end{tabular}

All (100\%) of the reviewed programs had targeted on creating or developing various Competences, twelve (80\%) of the programs aimed at Character, ten $(66.7 \%)$ on developing Confidence, five $(33.3 \%)$ programs aimed at promoting Caring, three (20\%) programs aimed at developing Connections. 


\subsection{Program Activities}

Programs goals were achieved by seventeen different types of activities (Table 1). Discussions $(82.4 \%)$, Small group exercise (58.8\%), Reflections (58.8\%), Lectures (52.9\%), Role-plays (47\%), and Games (47\%) are among the most frequently used activities. The other activities that were used trying to achieve the program goals are: Movie watching and discussion (17.6\%), Adult counseling and Case studies (11.8\% each). The rest of the activities (Mentoring, Peer-Mentoring, Interviews, Project assignment, Visits to other institutions, Weekend retreats, Theatre performing, Public events for school communities) were only used in one of the reviewed programs and constitute $5.9 \%$ of all activities used.

Table 2. Characteristics for the 15 evaluated programs

\begin{tabular}{|c|c|c|c|c|c|c|c|}
\hline & Program & Origin & Age & Activities & $\begin{array}{l}\text { Domains of } \\
\text { change }\end{array}$ & Structure & $\begin{array}{l}\text { Measurement of } \\
\text { outcomes (type of } \\
\text { outcomes) }\end{array}$ \\
\hline 1 & $\begin{array}{l}\text { Olweus Bullying } \\
\text { Prevention Program }\end{array}$ & Norway & $7-19$ & $\begin{array}{l}\text { Discussions } \\
\text { Small group } \\
\text { exercises } \\
\text { Reflections } \\
\text { Role-plays } \\
\text { Movie watching and } \\
\text { discussion } \\
\text { Individual } \\
\text { counseling sessions } \\
\text { Case studies } \\
\text { Public events for } \\
\text { school community }\end{array}$ & $\begin{array}{l}\text { Knowledge } \\
\text { Skills } \\
\text { Attitude }\end{array}$ & Yes & Yes (negative) \\
\hline 2 & $\begin{array}{l}\text { Big Brothers Big Sisters } \\
(\mathrm{BB} / \mathrm{BS})\end{array}$ & USA & $7-17$ & Mentoring & $\begin{array}{l}\text { Skills } \\
\text { Attitude }\end{array}$ & No & No \\
\hline 3 & Operation Snowball & USA & $14-18$ & $\begin{array}{l}\text { Discussions } \\
\text { Small group } \\
\text { exercises } \\
\text { Reflections } \\
\text { Lectures } \\
\text { Role-plays } \\
\text { Games } \\
\text { Counseling sessions } \\
\text { Weekend retreats } \\
\text { Theater } \\
\text { performances } \\
\text { Peer mentoring }\end{array}$ & $\begin{array}{l}\text { Knowledge } \\
\text { Attitude }\end{array}$ & Yes & $\begin{array}{l}\text { Yes (positive and } \\
\text { negative) }\end{array}$ \\
\hline 4 & $\begin{array}{l}\text { Drugs in the Schools: } \\
\text { Preventing } \\
\text { Abuse }\end{array}$ & USA & $13-16$ & $\begin{array}{l}\text { Discussions } \\
\text { Small group } \\
\text { exercises } \\
\text { Projects assignments }\end{array}$ & Knowledge & Yes & No \\
\hline 5 & $\begin{array}{l}\text { Life Skills Development } \\
\text { Programs }\end{array}$ & Lithuania & $5-16$ & $\begin{array}{l}\text { Discussions } \\
\text { Small group } \\
\text { exercises } \\
\text { Reflections } \\
\text { Games }\end{array}$ & $\begin{array}{l}\text { Knowledge, } \\
\text { Skills }\end{array}$ & No & No \\
\hline
\end{tabular}




\begin{tabular}{|c|c|c|c|c|c|c|c|}
\hline 6 & $\begin{array}{l}\text { Alcohol, Tobacco and } \\
\text { Other Substance Abuse } \\
\text { Prevention Program }\end{array}$ & Lithuania & $7-19$ & $\begin{array}{l}\text { Discussions } \\
\text { Small group } \\
\text { exercises } \\
\text { Reflections } \\
\text { Lectures } \\
\text { Role-plays } \\
\text { Games } \\
\text { Case studies } \\
\text { Interviews } \\
\text { Visits to the } \\
\text { institutions, that can } \\
\text { provide help and } \\
\text { assistance }\end{array}$ & $\begin{array}{l}\text { Knowledge, } \\
\text { Skills }\end{array}$ & No & No \\
\hline 7 & $\begin{array}{l}\text { Human Trafficking } \\
\text { Prevention program "A } \\
\text { Journey Turned into a } \\
\text { Nightmare" }\end{array}$ & Lithuania & $13-17$ & $\begin{array}{l}\text { Discussion } \\
\text { Reflections } \\
\text { Lectures } \\
\text { Games }\end{array}$ & $\begin{array}{l}\text { Knowledge } \\
\text { Attitude }\end{array}$ & Yes & No \\
\hline 8 & $\begin{array}{l}\text { Child and Human Rights } \\
\text { Training Program }\end{array}$ & Lithuania & $14-17$ & $\begin{array}{l}\text { Discussion } \\
\text { Reflections } \\
\text { Lectures } \\
\text { Role-plays } \\
\text { Games }\end{array}$ & $\begin{array}{l}\text { Knowledge } \\
\text { Attitude }\end{array}$ & Yes & No \\
\hline 9 & $\begin{array}{l}\text { Career Guidance and } \\
\text { Counseling Program }\end{array}$ & Lithuania & $13-17$ & $\begin{array}{l}\text { Discussion } \\
\text { Reflections } \\
\text { Lectures } \\
\text { Games }\end{array}$ & $\begin{array}{l}\text { Knowledge } \\
\text { Skills } \\
\text { Attitude }\end{array}$ & Yes & No \\
\hline 10 & Social resistance program & Lithuania & $13-17$ & $\begin{array}{l}\text { Discussions } \\
\text { Small group } \\
\text { exercises Lectures } \\
\text { Role-plays } \\
\text { Movie watching and } \\
\text { discussion }\end{array}$ & $\begin{array}{l}\text { Knowledge } \\
\text { Skills } \\
\text { Attitude }\end{array}$ & Yes & No \\
\hline 11 & Self-Awareness Program & Lithuania & $13-17$ & $\begin{array}{l}\text { Discussions } \\
\text { Small groups } \\
\text { exercises } \\
\text { Role-plays } \\
\text { Games }\end{array}$ & $\begin{array}{l}\text { Knowledge } \\
\text { Attitude }\end{array}$ & Yes & No \\
\hline 12 & $\begin{array}{l}\text { Social Skills Development } \\
\text { Program }\end{array}$ & Lithuania & $14-17$ & $\begin{array}{l}\text { Discussions } \\
\text { Small group } \\
\text { exercises } \\
\text { Reflections } \\
\text { Role-plays } \\
\text { Games }\end{array}$ & $\begin{array}{l}\text { Knowledge } \\
\text { Skills } \\
\text { Attitude }\end{array}$ & Yes & No \\
\hline 13 & $\begin{array}{l}\text { Adolescents' Resilience } \\
\text { Training Program }\end{array}$ & Lithuania & $14-17$ & $\begin{array}{l}\text { Discussions } \\
\text { Small group } \\
\text { exercises } \\
\text { Reflections } \\
\text { Lectures } \\
\text { Role-plays }\end{array}$ & $\begin{array}{l}\text { Knowledge } \\
\text { Skills }\end{array}$ & Yes & No \\
\hline
\end{tabular}




\begin{tabular}{|c|c|c|c|c|c|c|c|}
\hline 14 & $\begin{array}{l}\text { Preparation for Family Life } \\
\text { and Sexuality Education } \\
\text { Program }\end{array}$ & Lithuania & $15-16$ & $\begin{array}{l}\text { Discussions } \\
\text { Small group } \\
\text { exercises Lectures }\end{array}$ & $\begin{array}{l}\text { Knowledge } \\
\text { Attitude }\end{array}$ & No & No \\
\hline 15 & $\begin{array}{l}\text { Suicide Prevention } \\
\text { Program "Choose Life" }\end{array}$ & Lithuania & 16-19 & $\begin{array}{l}\text { Discussions } \\
\text { Reflections } \\
\text { Lectures } \\
\text { Movie watching and } \\
\text { discussion }\end{array}$ & $\begin{array}{l}\text { Knowledge } \\
\text { Attitude }\end{array}$ & Yes & No \\
\hline
\end{tabular}

Table 2 presents domains of change covered by activities in each program. Activities of almost all (93.3\%) evaluated programs (except "BB/BS") provided knowledge. This is the only domain of change in "Drugs in the Schools: Preventing Substance Abuse" program. Attitude change is the second frequent domain (covered by 10 programs or $66.6 \%)$. Slightly more than half of the programs $(53.3 \%)$ create opportunities to develop skills. Four programs $(27 \%)$ cover all three domains: provide knowledge, develop skills and change attitudes. Three programs (20\%) provide knowledge and develop skills, six (40\%) provide knowledge and change attitudes. One program ("BB/BS") develops skills and changes attitudes.

\subsection{Program Atmosphere}

Atmosphere was evaluated by program duration. Table 1 shows that the duration of all programs vary from three sessions to eighteen months. The duration of program (when specified) originated in Lithuania varies from three to eighteen sessions. Three out of eleven Lithuanian programs $(27.3 \%)$ did not specify the duration and/or frequency of the meetings.

The duration of programs that are not originated in Lithuania (four programs) vary from sixteen sessions to eighteen months. Three out of the four take more than six months.

\subsection{Measurement of Outcomes and Structure of the Curriculum}

We recorded, if the program outcomes were measured. The outcomes were measured only in "Olweus" and "Operation Snowball" programs (see Table 2). "Operation snowball" measures both reduction of negative and increase of positive outcomes and "Olweus" measures only reduction of negative outcomes.

Eleven programs (73.3\%) out of fifteen have structured curriculum. All the programs with unspecified duration have no structured curriculum as well. These programs provide the list of activities suggested according to some topics or goals to achieve.

\section{Discussion}

This review aimed at evaluating youth development programs for late adolescents (15-19 years) implemented in Lithuania in 2006-2013. Fifteen programs were identified, eleven (73.3\%) were originated in Lithuania while the other four $(26.7 \%)$ in other countries (USA and Norway). The programs were evaluated according to their correspondence to positive youth development philosophy. We used the criteria of positive youth development programs identified by Roth \& Brooks-Gunn (2003): program goals, activities and atmosphere. We also included measurement of program outcomes and structure of the curriculum as additional criteria.

The range of goals offered by the programs match all the 5Cs of thriving. Only two (13.3\%) programs, however, adopt goals reflecting the full spectrum of positive development. Promotion of Competence, Character and Confidence was the most frequent goal targeted by programs reviewed whereas Caring and Connections were targeted less. It is not surprising, since youth development programs in Lithuania are mostly under the label of prevention and see the reducing substance abuse and problem behaviors as their primary goals (46.7\%). Analysis of program outcome measurement also reflects the focus on reducing negative consequences: positive outcomes were evaluated only in "Operation Snowball" program. Besides, life skills approach is the prevention strategy that is often being used in Lithuanian youth development programs (in five (33.3\%) of the programs reviewed in current study). Life skills can be compared to the concept of developmental assets, which is an integral part of positive youth development perspective (Weichold, 2007). However, life skills programs foster mainly internal assets and are rather limited in fostering external ones, which are related to supportive relationships with others. This explains why Lithuanian prevention programs are not aimed at promotion of Caring and Connections as much as Competence, Character and Confidence. 
The second defining feature of youth development program identified by Brooks-Gunn (2003) is program activities. Activities that capture positive youth development philosophy include the opportunity for adolescents to 1) build skills, 2) engage in real and challenging activities, 3) broaden their horizons and 4) increase developmental supports in other contexts of adolescents' worlds, such as family, school, or community. Less than a half of the programs implemented in Lithuania included in this review provide the possibility to build skills. Few programs engage participants in real and challenging activities, since most of them are implemented in the classroom environment. Opportunities for Lithuanian adolescents to broaden their horizons are limited as well since few programs suggest activities, where participants have possibilities to visit other institutions, meet new people or situations. Lithuanian programs are focused on changes at the individual level, therefore those programs do not increase developmental supports in other contexts of adolescents' worlds. The analysis of domains of change revealed, that most of the programs (with some exceptions such as "BB/BS") focus on knowledge and attitude change and use lectures and discussions, i.e. methods that are not suitable for developing skills and providing sufficient opportunities for positive youth development.

Program atmosphere is the third defining feature of PYD programs. Roth and Brooks-Gunn (2003) have identified five dimensions of program atmosphere, but we used only duration and relationship-focused activities as indicators of program atmosphere because this was the only available information from the program descriptions. Lithuanian positive youth development programs are of shorter duration than the ones originated in USA or Norway. The duration of program is one of the prerequisites to develop and foster relationships, therefore Lithuanian youth development programs provide fewer opportunities for supportive relationships than programs originated in USA or Norway. As referred by Catalano et al. (2004), effective, well-evaluated programs usually are delivered over a period of nine months or longer. Those operating in a school domain, apply their interventions usually during the academic year. Programs being implemented in Lithuania, especially those of Lithuanian origin, are at least half shorter with several exceptions only. Time is one of the necessary features that allow for the development of strong relationships that are crucial for fostering positive outcomes. Catalano et al. (2004) also suggest, that for the program to be effective at least 10 sessions are needed. Most of the analyzed programs meet this criteria. However, it should be noted that one fifth of the programs provide only list of activities without specifying the duration and/or frequency of the meetings. Presence of prerequisites for supportive atmosphere cannot be inferred from these descriptions.

Program components that include mentoring provide the opportunity for youth to develop supportive relationships with adults, or in the case of peer mentoring or tutoring, supportive relationships with other youth (Roth \& Brooks-Gunn, 2003b). Only four programs (26.7\%) implemented in Lithuania suggest relationship-focused activities: two offer adult counseling, one adult mentoring and one peer mentoring. This also supports the conclusion that youth centered program atmosphere is not sufficiently encouraged in Lithuanian context.

Although program implementation and assurance of implementation quality is one of the most important topics in the positive youth development field (Catalano et al., 2004), we excluded this criteria from the current review since it is not possible to establish if this was indeed carried out from available program description. This limitation of the review suggests future developers of youth development programs should include the measurements of the effectiveness in their plans.

\section{Conclusion}

With no national registry and no tradition of evaluating program outcomes, the effectiveness of youth development programs implemented in Lithuania is unknown. The effectiveness of "Operation Snowball", Big Brothers Big Sisters, and Olweus Bullying Prevention Program is internationally proven. These programs are oriented to system changes that correspond well to PYD philosophy. However, only some aspects of effectiveness of Olweus Bullying Prevention Program and "Operation Snowball" were measured in Lithuania. Those programs were shown to be effective in reducing negative and promoting some positive outcomes (Povilaitis \& Bulotaitè, 2014; Vareikienė \& Zaborskis, 2012; Goštautas \& Pilkauskienè, 2004).

The current study represents an attempt to review youth development programs implemented in Lithuania within positive youth development perspective. This review showed that these programs contain several features consistent with PYD conception. Roth \& Brooks-Gunn (2003) indicated two components that are of utmost importance, namely program goals and atmosphere. Although programs implemented in Lithuania are aimed at developing all Cs to various degrees, the atmosphere component is largely overlooked if present at all. According to PYD perspective, the role of youth development programs is to provide internal and external developmental assets for making positive outcomes. While no single program implemented in Lithuania can be 
truly named positive youth development program, development of youth programs should use PYD conception as their theoretical basis.

Structure is one of the merits of the programs being implemented in Lithuania. As Catalano et al. (2004) argues, structure of the curriculum or activities is critical for program replication, which makes future evaluation of program effectiveness possible. We suggest program developers to use experimental or quasi-experimental designs for the measurement of program outcomes.

Overall, the programs reviewed are partly consistent with PYD, but their effect is uncertain, because of the absence of the most important features of effective youth development programs identified in other cultural contexts.

\section{Acknowledgments}

This research is/was funded by the European Social Fund under the Global Grant measure, VP1-3.1-ŠMM-07-K-02-008.

\section{References}

Benson, P. L. (2003). Developmental assets and asset-building community: Conceptual and empirical foundation. In R. M. Lerner, \& P. L. Benson (Eds.), Developmental assets and asset-building communities: Implication for research, policy and practice (pp. 19-43). New York: Kluwer Academic/Plenum Press. http://dx.doi.org/10.1007/978-1-4615-0091-9_2

Catalano, R. F., Berglund, M. L., Ryan, J. A. M., Lonczak, H. S., \& Hawkins, J. D. (2004). Positive youth development in the United States: Research findings on evaluations of positive youth development programs. The ANNALS of the American Academy of Political and Social Science, 98-124. http://dx.doi.org/10.1177/0002716203260102

King, P. E., Dowling, E. M., Mueller, R. A., White, K., Schultz, W., Osborn, P., ... Scales, P. C. (2005). Thriving in Adolescence: The voices of youth-serving practitioners, parents, and early and late adolescents. Journal of Early Adolescence, 25(1), 94-112. http://dx.doi.org/10.1177/0272431604272459

Lerner, J. V., Phelps, E., Forman, Y., \& Bowers, E. P. (2009). Positive youth development. In R. M. Lerner, \& L. Steinberg (Eds.), Handbook of adolescent psychology. Vol.1: Individual bases of adolescent development (3rd ed., pp. 524-558). New Jersey, NJ: John Willey \& Sons, Inc. http://dx.doi.org/10.1002/9780470479193.adlpsy001016

Lerner, R. M. (2004). Diversity in Individual $\leftrightarrow$ Context Relations as the Basis for Positive Development Across the Life Span: A Developmental Systems Perspective for Theory, Research, and Application (The 2004 Society for the Study of Human Development Presidential Address). Research in Human Development, 1(4), 327-346. http://dx.doi.org/10.1207/s15427617rhd0104_5

Lerner, R. M., Dowling, E. M., \& Anderson, P. M. (2003). Positive youth development: Thriving as the basis of personhood and civil society. Applied Developmental Science, 7(3), 172-180. http://dx.doi.org/10.1207/S1532480XADS0703_8

Lerner, R. M., von Eye, A., Lerner, J. V., Lewin-Bizan, S., \& Bowers, E. P. (2010). Special issue introduction: The meaning and measurement of thriving: A view of the issues. Journal of Youth and Adolescence, 39(7), 707-719. http://dx.doi.org/10.1007/s10964-010-9531-8

Roth, J. L., \& Brooks-Gun, J. (2003a). Youth development programs: Risk, prevention and policy. Journal of Adolescent Health, 32, 170-182. http://dx.doi.org/10.1016/S1054-139X(02)00421-4

Roth, J. L., \& Brooks-Gun, J. (2003b). What exactly is a youth development program? Answers from research $\begin{array}{llll}\text { and } & \text { Applied }\end{array}$ http://dx.doi.org/10.1207/S1532480XADS0702_6

Scales, P. C., Benson, P. L., Leffert, N., \& Blyth, D. A. (2000). Contribution of developmental assets to the prediction of thriving among adolescents. Applied Developmental Science, 4(1), 27-46. http://dx.doi.org/10.1207/S1532480XADS0401_3

Silbereisen, R. K., \& Lerner, R. M. (2007). Approaches to positive youth development: A view of the issues. In R. K. Silbereisen, \& R. M. Lerner (Eds.), Approaches to positive youth development (pp. 3-30). Thousand Oaks, CA: Sage. http://dx.doi.org/10.4135/9781446213803.n1 
Theokas, C., Almerigi, J., Lerner, R. M., Dowling, E., Benson, P., Scales, P. C., \& Von Eye, A. (2005). Conceptualizing and modeling individual and ecological asset components of thriving in early adolescence. Journal of Early Adolescence, 25(1), 113-143. http://dx.doi.org/10.1177/0272431604272460

Weichold, K. (2007). Prevention against substance misuse: Life skills and positive youth development. In R. K. Silbereisen, \& R. M. Lerner (Eds.), Approaches to positive youth development (pp. 293-310). Thousand Oaks, CA: Sage. http://dx.doi.org/10.4135/9781446213803.n16

Yibing, L., Lerner, J. V., \& Lerner, R. M. (2010). Personal and Ecological Assets and Academic Competence in Early Adolescence: The Mediating Role of School Engagement. Journal of Youth and Adolescence, 39, 801-815. http://dx.doi.org/10.1007/s10964-010-9535-4

Auškelis, R., Dulinskaitè, I., \& Valantiejienè, S. (2010). Lietuvoje igyvendinamos prevencinès programos, Tarptautineje praktikoje taikomos prevencinès programas ataskaita. Vilnius, Specialiosios pedagogikos ir psichologijos centras.

Goštautas, A., \& Pilkauskienė, I. (2004). Intensyvus mokymas bendravimo psichologijos mokykloje. Kaunas, VDU leidykla.

Povilaitis, R., \& Bulotaite, L. (2014). Prevention of bullying in Lithuania. International Journal of Mental Health Promotion, 16(1), 28-41. http://dx.doi.org/10.1080/14623730.2013.857826

Vareikienè, I., \& Zaborskis, A. (2012). Mokiniu psichologinès savijautos pokyčiai, ịvykdžius Olweus patyčiu prevencijos programą Kauno Miesto Mokyklose. Visuomenès Sveikata, 4(59), 59-66.

\section{Appendix A}

Table A1. Lithuanian titles of the 15 evaluated programs

\begin{tabular}{|c|c|c|c|}
\hline & English title & Lithuanian title & Origin \\
\hline 1 & Olweus Bullying Prevention Program & $\begin{array}{l}\text { Olweus patyčiu ir smurto prevencijos } \\
\text { programa }\end{array}$ & Norway \\
\hline 2 & Big Brothers Big Sisters (BB/BS) & Didysis Broils Didžioji Sesuo & USA \\
\hline 3 & Operation Snowball & Sniego gniūžtė & USA \\
\hline 4 & $\begin{array}{l}\text { Drugs in the Schools: Preventing Substance } \\
\text { Abuse }\end{array}$ & $\begin{array}{l}\text { Kaip nuo narkomanijos apsaugoti } \\
\text { "Svajonės" mokyklą }\end{array}$ & USA \\
\hline 5 & Life Skills Development Programs & Gyvenimo igūdžių ugdymo programa & Lithuania \\
\hline 6 & $\begin{array}{l}\text { Alcohol, Tobacco and Other Substance } \\
\text { Abuse Prevention Program }\end{array}$ & $\begin{array}{l}\text { Alkoholio, tabako ir kitų psichiką } \\
\text { veikiančiu medžiagų vartojimo prevencijos } \\
\text { programa }\end{array}$ & Lithuania \\
\hline 7 & $\begin{array}{l}\text { Human Trafficking Prevention program "A } \\
\text { Journey Turned into a Nightmare" }\end{array}$ & $\begin{array}{l}\text { Košmarais virtusios kelionès - prekybos } \\
\text { žmonėmis prevencija }\end{array}$ & Lithuania \\
\hline 8 & Child and Human Rights Training Program & Vaiko ir žmogaus teisių mokymai & Lithuania \\
\hline 9 & Career Guidance and Counseling Program & $\begin{array}{l}\text { Profesinio orientavimo ir informavimo } \\
\text { programa }\end{array}$ & Lithuania \\
\hline 10 & Social resistance program & Socialinio atsparumo programa & Lithuania \\
\hline 11 & Self-Awareness Program & Savęs pažinimo programa & Lithuania \\
\hline 12 & Social Skills Development Program & Socialinių igūdžių ugdymo programa & Lithuania \\
\hline 13 & Adolescents' Resilience Training Program & $\begin{array}{l}\text { Paauglių psichologinio atsparumo ugdymo } \\
\text { programa }\end{array}$ & Lithuania \\
\hline 14 & $\begin{array}{l}\text { Preparation for Family Life and Sexuality } \\
\text { Education Program }\end{array}$ & $\begin{array}{l}\text { Rengimo šeimai ir lytiškumo ugdymo } \\
\text { programa }\end{array}$ & Lithuania \\
\hline 15 & Suicide Prevention Program "Choose Life" & $\begin{array}{l}\text { Savižudybių prevencijos programa } \\
\text { "Renkuosi gyvenimą" }\end{array}$ & Lithuania \\
\hline
\end{tabular}




\section{Copyrights}

Copyright for this article is retained by the author(s), with first publication rights granted to the journal.

This is an open-access article distributed under the terms and conditions of the Creative Commons Attribution license (http://creativecommons.org/licenses/by/3.0/). 